\title{
How Britain's and Colombia's Privileged Partnerships with the United States Influenced Their Respective Journeys through the European Community and UNASUR ${ }^{1}$
}

\author{
László PALOTÁS ${ }^{20}$
}

\begin{abstract}
This paper explores how Britain's and Colombia's privileged relations with the United States (U.S.) influenced their journey through the European Community (EC) and the Union of South American Nations (UNASUR). The Anglo-American Special Relationship (AASR) was compatible with British participation in the European Single Market, but not with adherence to creating the EC's common currency, nor with leadership in building a European defence structure autonomous from NATO. Thus, since the start of the Iraq war, Britain played a rather obstructive role in what later was called European Common Security and Defence Policy (CSDP). The US-Colombia Partnership (USCP), based on a longstanding military association reinforced under Plan Colombia, naturally discouraged any meaningful Colombian participation in UNASUR's South American Security Council (CDS), a regional cooperative security project, promoted by Brazil. Cherished projects of the liberal CAP - such as triangular cooperation (to export Colombian security expertise to Central America with U.S. co-financing and oversight) and NATO partnership - also distracted Colombia's interest from UNASUR, diminishing the latter's relevance collaterally. A role for UNASUR - alongside the Organization of American States (OAS) - in South American security management was compatible with the liberal CAP, but not with the neoconservative CAP. Even a lopsided complementation - such as the one between NATO and the CSDP - proved unviable between the OAS and UNASUR.
\end{abstract}

Keywords: Anglo-American Special Relationship, Colombo-American Partnership, European Community/Union, Common Security and Defence Policy, UNASUR, South American Defense Council, collateral, exclusive, inter/ intra-institutional balancing

Paper based on research project 'Colombia and Britain: special relations with the United States -withdrawals from regional schemes’, UNI050614151031, UNICIENCIA University, CISE Center for Research and Corporate Services, Group GIDEC, Bucaramanga, Colombia.

2 PhD, professor at the UNICIENCIA Bucaramanga, Colombia, e-mail: donlaszlo1@gmail.com 


\section{Introduction}

The U.S. has maintained privileged hierarchical relationships with Britain $^{3}$ and Colombia, both adjacent to regions of great American influence. Britain is located on the rim of Western Europe, although it has retained its global maritime horizon. Colombia is situated between the Caribbean Basin, where U.S. influence has been highest, and the Southern Cone, where it has been much lower.

This paper surveys the influence of the Anglo-American Special Relationship (AASR) and the Colombo-American Partnership (CAP) on Britain's and Colombia's respective journeys through the European Community (EC) ${ }^{4}$ and the Union of South American Nations (UNASUR), including their entry, limited participation and exit. It reviews both influences and journeys according to the same concepts, and makes some comparisons.

Although not a special relationship, the CAP is based on a longstanding, highly institutionalised security association and, more recently, exclusive cooperation in fighting transnational organised crime. ${ }^{5}$ Colombia is NATO's only partner in Latin America. Pro-Americanism is traditionally high among Colombian elites, perfectly coupled to their American peers, and (to a somewhat lesser extent) at grassroots' level as well.

UNASUR comprised the quite peaceful Southern Cone (Argentina, Brazil, Uruguay, Paraguay), and the more turbulent Andean Crest (Colombia, Venezuela, Ecuador, Peru, Bolivia, Chile), along with former British and Dutch colonies, tiny Guyana and Surinam.

Certainly, changes in the AASR and the CAP impacted Britain's and Colombia's regional ties in Europe and South America, concerning regional integration-cooperation processes substantially. UNASUR was even created essentially as a Brazilian reaction to Plan Colombia.

Conversely, British and Colombian conducts within - or concerning - the EC and UNASUR, affected the AASR and the CAP, remaining compatible or becoming incompatible with them.

\section{Conceptual framework}

This section describes key concepts that help explain how did the AASR and the CAP influence Britain's journey through the EC and Colombia's passage through UNASUR.

3 Or Great Britain or the U.K.: United Kingdom of Great Britain and Northern Ireland.

4 EC denotes in this text not only the European Community, but also the European Economic Communities (EEC) and the European Union (EU).

5 This cooperation emerged from Plan Colombia, a multibillion-dollar CAP effort to stabilise the country and fight the intertwined drug and guerrilla war (Adam Isacson, 'It's Not Too Late for the Land of Mercenaries', The New York Times, 05 August 2021). 
Hard and soft balancing: U.S. ambivalence toward European integration

Rees contrasts U.S. Atlanticism (viewed through liberal institutionalist lens) with America's ambivalent attitude towards European integration (depicted in neorealist terms). ${ }^{6}$

Facing perceived Soviet threat, America built a liberal Atlantic order with Western European allies, stationing its conventional forces in their territories and providing them nuclear protection. Despite power disparity, the U.S. led NATO as primus inter pares, which allowed allies acting in cohesion.?

America's support for European integration proved more ambiguous. Although the U.S. voiced backing for integration as a means of European unity, it was aware that - being an outsider - it had limited influence on the EC's trajectory. ${ }^{8}$

With time, there was a risk that the EC would evolve into an institutional framework antagonistic towards the U.S. Between Atlanticism and European integration existed the potential for future conflict. For realists, America faced the efforts of others to counterbalance its power. ${ }^{9}$ Posen saw European defence efforts as an attempt to challenge American hegemony through hard balancing. ${ }^{10}$

For others, the problem was the EC's weakness. Lacking hard resources to counterbalance the U.S., the EC resorted to soft balancing through the creation of the euro or the use of international institutions. The capabilities of the EC's Common Security and Defence Policy (CDSP) were designed to complement NATO structures, rather than to compete with them. ${ }^{11}$

\section{Varieties of institutional balancing - EU-CSDP, NATO, UNASUR-CDS, OAS}

Both the EC's CSDP and UNASUR's CDS fitted into several types of institutional balancing (that is soft balancing through institutions).

\section{Exclusive institutional balancing}

This type of balancing emphasises the exclusion of the target state (primary power) from an institution (cooperation process) by one or more balancing states. ${ }^{12}$ The U.S. was

${ }_{6}$ Wyn Rees, 'America, Brexit and the security of Europe', British Journal of Politics and International Relations 19, no 3 (2017).

7 Ibid. 3.

8 Ibid. 4.

9 Ibid.

10 Barry Posen, 'EU security and defence policy: Response to unipolarity?', Security Studies 15, no 2 (2006).

11 Stephen Brooks and William Wohlforth, 'Hard Times for Soft Balancing', International Security 30, no 1 (2005).

12 Kai He, 'Contested Regional Orders and Institutional Balancing in the Asia Pacific', International Politics 52, no 2 (2015), 215. Daniel Flemes and Rafael Castro, 'Institutional Contestation: Colombia in the Pacific Alliance', Bulletin of Latin American Research 35, no 1 (2016), 81. 
excluded from the EC, led by France and Germany. The U.S. (and Mexico) could not access UNASUR, led by Brazil.

Britain and Colombia - although members of these regional organisations - kept their strongest bilateral ties to the excluded global power. Hence the expectation of incompatibilities between their partnership with the U.S. and their regional cooperationintegration commitments.

\section{Inter-institutional balancing}

In this type of balancing, one (regional) institution is used to challenge the relevance of another. ${ }^{13}$

In its early years, UNASUR challenged the relevance of the OAS in South American security management (conflict resolution and democracy protection), since a critical mass of left-wing leaders led by Brazilian president Lula da Silva (able to attract others from the centre-right like Colombia's Juan Manuel Santos) acted quickly and efficiently on crises within and between countries in the region.

In 2013, German researchers still saw potential for division of labour between the UNASUR and the OAS, ${ }^{14}$ but warned: UNASUR's formation was a largely antagonistic process, aimed at weakening the influence of OAS in South American affairs. ${ }^{15}$

The CSDP did not challenge NATO's relevance, nor was entirely separate from it, but rather complementary. Still, when the Brexit process removed the habitual British veto on CSDP's deepening in 2017, the EU resumed its efforts towards some sort of strategic autonomy, creating some modest tools as the Permanent Structured Cooperation (PESCO) or the European Defence Fund (EDF). ${ }^{16}$

Paradoxically, while the U.S. is pushing the EU to advance on its self-defence capacities, once these advancements are made, it tries to frame them inside NATO or block them. The U.S. perceives anything within NATO as under its control. If the EU develops its strategic autonomy, and the U.S. perceives that structure as non-aligned with NATO, it will consider the EU an external player and thus a geopolitical rival. ${ }^{17}$

13 A state supports institution " $A$ " to undermine the influence of institution " $\mathrm{B}$ " if the latter does not respond to its interests (Ibid. 215, 217).

14 South American leaders would resolve conflicts at the sub-regional level, and the OAS would focus on problems affecting the entire hemisphere. Brigitte Weiffen, Leslie Wehner and Detlef Nolte, 'Overlapping regional security institutions in South America: The case of OAS and UNASUR', International Area Studies Review 16, no 4 (2013), 385.

15 Ibid.

16 Edgar Jiménez García, 'El ejército europeo y la PESCO: OTAN o nada’, Instituto Español de Estudios Estratégicos, Documento de Opinión no 97 (2019), 9.

17 Ibid. 18-19. 


\section{Competition between nested organisations}

Conflict potential is particularly high, when two nested regional organisations (that is, a larger one comprising all the member states of a smaller one) overlap in their main mandate as well. Such organisations tend to clash over the exclusive right to exercise that mandate within a regional domain. ${ }^{18}$

UNASUR was nested in the OAS, and the two organisations disputed the mandate of security management in South America, until "nested" members kept their dual membership alive. Nevertheless, overlaps in their actions occasionally led to outcomes beneficial to regional cooperation (until the Venezuelan multi-crisis became intractable in 2016). ${ }^{19}$

NATO (30) has 21 members in common with the EU (27). ${ }^{20}$ The mandates of the CSDP and NATO overlapped most clearly in crisis management. NATO-CSDP complementation focused on avoiding duplication of functions. However, reconciling the EU's quest for strategic autonomy and enhanced cooperation with NATO could be difficult. ${ }^{21}$

\section{Intra-institutional balancing}

In order to capture cooperative conducts in institutional balancing, along with competitive ones, Lee distinguishes analytically between inter- and intra-institutional balancing. ${ }^{22}$

According to the latter (which adds a drop of liberal institutionalism to an otherwise neorealist conception), states cooperate to create an institution, when demand for collective goods is high. But once the institution providing the collective good is created, they show within its framework both cooperative and competitive (balancing) behaviours. ${ }^{23}$

In the EC, the collective good which attracted Britain was the Single Market. In UNASUR, Brazil tried to provide regional stability, by assembling a cooperative security scheme, aimed at building a pluralist security community, ${ }^{24}$ or regional autonomy. ${ }^{25}$

British and Colombian cooperative conducts within the EC and UNASUR (contributing to regional integration) could be expected to diverge from the AASR and the CAP.

18 Detlef Nolte, 'Costs and Benefits of Overlapping Regional Organizations in Latin America: The Case of the OAS and UNASUR', Latin American Politics and Society 60, no 1 (2018), 129, 147.

19 Ibid.

20 The nine NATO countries outside the EU include the U.S. and lately Britain. The six EU members outside NATO include 4 neutrals.

21 Maria Eleni Koppa, 'The relationship between CSDP and NATO after Brexit and the EU’s Global Strategy', FEPS Studies, April 2019.

22 Seungjoo Lee, 'Institutional Balancing and the Politics of Mega-FTAs in East Asia', Asian Survey 56, no 6 (2016).

23 Ibid. 1063.

24 Mélanie Lepage, Vers le développement d'une communauté de sécurité pluraliste en Amérique du Sud avec la mise en place de l'Union des nations sud-américaines (Université Laval, IQHEI, Avril 2011).

25 Victor Mijares, 'Performance of the South American Defense Council Under Autonomy Pressures', Latin American Policy 9, no 2 (2018). 


\section{Collateral balancing}

CAP projects, privileged by Colombia, had repercussions on other states or regional schemes. Such collateral effects could amount to hard balancing. Although not directed against Brazil, Plan Colombia enhanced U.S. military presence in its neighbour. Moreover, the Plan was inserted into the U.S. global war on terror by the neoconservative George W Bush - Álvaro Uribe duo. Thus, it prompted the Lula Government to establish UNASUR and endow it with the CDS. ${ }^{26}$

Likewise, the Defense cooperation agreement (ACD) on formal U.S. access to Colombian bases did not target Brazil but challenged its geostrategic interests anyway as the primary power in South America (and the Amazon). ${ }^{27}$

In other cases, collateral balancing was soft (inter-institutional): for example, Colombia's NATO partnership (in line with the CAP) was not directed against UNASUR, but still undermined its relevance, by distracting Colombia from cooperation within the CDS.

\section{Institutional contestation}

Less innocently, others saw Colombia's rapprochement to NATO as a tool of deliberate institutional contestation: a strategy of secondary powers in a region to question the legitimacy, centrality or effectiveness of institutions led by primary powers. ${ }^{28}$

Institutional contestation (along with exclusive and inter-institutional balancing) is a form of buffering: the strategy of a secondary power that deepens its economic and security cooperation with other states in order to increase its influence over the primary power. ${ }^{29}$

While the Uribe Government was willing to hard balance Brazil collaterally, the Santos Administration resorted only to (soft) buffering tools vis-à-vis the big South American neighbour. ${ }^{30}$

\section{Structure of analysis}

Applying the above conceptual framework, the next two sections examine how the AASR influenced Britain's passage through the EC, and how the CAP influenced Colombia's passage through UNASUR: entry, limited participation, exit.

\footnotetext{
26 Olivier Dabène, 'La cuarta ola de regionalismo', in Los desafíos del desarrollo en América Latina, ed. by Carlos Quenan and Sébastian Velut (Paris: Institut des Amériques, 2014), 84-85.

27 Daniel Flemes and Leslie Wehner, 'Drivers of strategic contestation: The case of South America', International Politics 52, no 2 (2015).

28 Flemes and Castro, 'Institutional Contestation', 84.

29 Ibid. 81.

30 Ibid.
} 
Subsections on those limited participations check to what extent Britain's competitive conducts within the EC converged with - and its cooperative behaviours diverged from - the AASR, and whether the cooperative behaviours remained compatible or became incompatible with it.

They also review to what extent Colombia's competitive behaviours within UNASUR converged with - and its cooperative conducts diverged from - the CAP, and whether the cooperative ones were compatible or incompatible with it.

For a more nuanced picture of these (in)compatibilities, the CAP is adjusted with the ideological composition of presidential duos: neoconservative, liberal, mixed CAP. ${ }^{31}$

The same subsections explore the effects of the AASR on British behaviours concerning CSDP/NATO complementation, as well the effects of the CAP on Colombian strategies relative to UNASUR/OAS competition.

\section{Influences of the AASR on Britain's passage through the EC}

Entry: delayed and then urged by the AASR indirectly

French President Charles de Gaulle - who saw Britain as America's Trojan horse because of its strong attachment to the AASR and NATO - vetoed British EC accession twice, delaying it for a decade. Meanwhile, U.S. diplomacy redirected toward the EC and (after the French withdrawal from NATO's integrated military command in 1966) Federal Germany. ${ }^{32}$ The sidelining of the AASR in transatlantic relations pushed Britain to enter the EC.

When Britain first applied to the EC in 1961, people were polled which entity they would join, if they had the choice: the USA or Europe? 55 per cent of the respondents preferred the U.S. and only 22 per cent Europe. ${ }^{33}$

President John F Kennedy (before the British candidature was presented) assured Prime Minister Harold Macmillan that the AASR "would be strengthened and not weakened” if London moved towards EC membership. ${ }^{34}$ Macmillan adopted a strategy of "hedging", by which the AASR would remain priority, and would only be complemented, as an insurance policy, with a new power base in Europe. ${ }^{35}$

But Macmillan's attachment to the AASR thwarted his efforts to join the EC. In early 1963, de Gaulle not only rejected Kennedy’s ‘Grand Design’ - which envisaged a multilateral nuclear force integrating U.S., British and French capabilities under U.S. command - as incompatible with his desire to create a national force of deterrence, but

The AASR does not normally require such a distinction, as illustrated by the Bush-Blair "bromance".

32 David Reynolds, ‘A 'special relationship’? America, Britain and the international order since the Second World War’, International Affairs 62, no 1 (1985).

33 Rebekah Brown, 'History of the Anglo-American Special Relationship', Ashbrook Statesmanship Thesis, 2012, 25.

34 Reynolds, ‘A ‘special relationship’?’, 14.

35 Nigel Ashton, 'Harold Macmillan and the 'Golden Days' of Anglo-American relations revisited, 1957-63', Diplomatic History 29, no 4 (2005). 
he also cited the Anglo-American missile agreement ${ }^{36}$ as evidence of Britain's innate Atlanticism, vetoing its EC candidacy. ${ }^{37}$

In 1967, the General again vetoed British accession to the EC, which would only materialise in 1973, four years after his resignation.

\section{Limited participation}

After taking part in the construction of the Single European Market, Britain remains outside the great supranational EC projects, such as the common currency, and (barring a brief period) plays a largely obstructive role in the CSDP.

\section{Single market: British cooperative behaviour within the EC-compatible with the} AASR

PM Margaret Thatcher signs the Single European Act of $1986 .{ }^{38}$ Britain was actively involved in standards' harmonisation and financial liberalisation. While the single market discriminated against third parties such as the U.S., it also benefited U.S. companies established in Britain, particularly financial services firms. ${ }^{39}$

\section{Saint-Malo: British cooperative conduct within the EC - diverges from the AASR}

In the 1998 Saint-Malo Declaration, PM Tony Blair embraces the need to provide the EU with capability for "autonomous action backed up by credible military forces" in order to respond to international crises when NATO is not involved. ${ }^{40}$

This Anglo-French agreement laid the ground for launching the Common Foreign and Security Policy (CFSP) in 1999, leading to the CSDP in 2009.

During the Bosnian conflict (1992-1995), Europeans - including the British - realised their over-dependence on the U.S. ${ }^{41}$ Saint-Malo was a real compromise: the British adhered

36 The deal provided for British nuclear submarines to be equipped with U.S. made ballistic missiles.

37 Robert Frank, Être ou ne pas être Européen? Les Britanniques et l'Europe du XVIIe siècle au Brexit (Paris: Belin, 2018), 216-217; Lawrence Freedman, 'Britain Adrift. The United Kingdom’s Search for a Post-Brexit Role', Foreign Affairs, May-June 2020.

38 Commission President Delors ably convinced Thatcher, proposing a project imbued by economic liberalism that could only please her: a "single market” that guarantees completely free movement of people, goods, services and capital. Frank, Etre ou ne pas être, 240-241.

39 These firms could freely provide their services to customers located in any other EC (and European Economic Area) country, thanks to a "passport" system.

40 'Joint Declaration on European Defence, issued at the British-French Summit, Saint-Malo', 04 December 1998.

41 They could not end this war alone, although the Soviet threat ceased to exist (IRIS France, 'Être ou ne pas être européen? Les Britanniques et l'Europe du XVIIe siècle au Brexit - 3 questions à Robert Frank'. Le point de vue de Pascal Boniface, 28 March 2019). 
to the plan of EC autonomy in military crisis response, and the French agreed to rejoin NATO a bit more. ${ }^{42}$

With Saint-Malo, the EU (which abandoned its traditional civilian identity) “overlapped” with NATO (whose post-Cold War diversification included anti-crisis operations) in its main mandate. ${ }^{43}$ The U.S. tried to prevent the CFSP from taking root. ${ }^{44}$ British leadership in this new field would have affected the AASR.

\section{Opt-outs: British competitive behaviours within the EC - converge with the AASR}

PM John Major's government obtains opt-outs from future EU common policies. In order to pass the Maastricht Treaty of 1992 through the British parliament (against Eurosceptic resistance), Major obtained in Brussels an opt-out from the monetary union. When negotiating the 1997 Treaty of Amsterdam, he got another opt-out from the dismantling of intra-EU border controls (Schengen area) as well as a flexible opt-out of shared policies on internal security and justice.

With all these opt-outs, the British membership turns de facto partial, but Britain remains fully involved in EU decision-making ${ }^{45}$ - an optimal arrangement for the AASR.

\section{Eastward extension as a competitive British strategy within the EU - converges with the AASR}

Britain promotes the EU's extension to the east in order to dilute its western core and slow down its deeper integration. In 2004 and 2007, the EU incorporated a dozen central and eastern former Communist countries. ${ }^{46}$ Their fervent Atlanticism was an added benefit for the AASR. ${ }^{47}$

\section{Obstruction of the CSDP: competitive conduct within the EU and pro-NATO strategy in the complementation - converges with the AASR}

Saint-Malo's promises were never fulfilled. Since the start of the Iraq War in 2003, Britain played a largely obstructive role in the CSDP, by diluting and vetoing in the name of the U.S. the initiatives that would have made the EU more autonomous in defence. ${ }^{48}$

42 Ibid.

43 Lorenzo Cladi and Andrea Locatelli, 'Keep Calm and Carry On (Differently): NATO and CSDP after Brexit', Global Policy 11, no 1 (2020).

44 Tomáš Valášek, 'European defense vs. NATO: Not the right fight’, Politico, 19 February 2018.

45 Barbara Lippert and Nicolai von Ondarza, 'Der Brexit als Neuland', SWP Aktuell no 42 (2016), 6.

46 Britain granted full labour rights to intra-EU immigrants immediately, without transition period. "Taking back control” would then be the strongest pro-Brexit driver at the 2016 referendum.

47 Rees, 'America, Brexit', 6.

48 For example, in 2003 and 2011, Britain vetoed EU proposals to set up a comprehensive planning headquarters (for the CSDP), because it could have affected NATO’s unique capabilities (Rees, 'America, Brexit', 7). 
The myriad of compromises rendered the CSDP inoperative, and the British contribution to its actions was always negligible. With their defence inextricably tied into the American defence, the British never took the idea of European defence too seriously. Indebted to the Americans, they tried to block European cooperation initiatives such as Galileo. Their troops assigned to EU battle groups withdrew well ahead of the late 2019 elections that confirmed Brexit. $^{49}$

\section{Brexit - influenced by the AASR indirectly}

The U.S. inadvertently contributed to the Brexit vote, by using the AASR to manage its ambiguous relationship with the EU in defence. ${ }^{50}$

When the U.S. used Britain to constrain the EU's range of defence capabilities, it fuelled British misgivings about its value. ${ }^{51}$ When the U.S. involved Britain in bilateral cooperation, instead of using it as a transatlantic bridge, ${ }^{52}$ it cultivated in the British people an image of their country as a natural ally of America, rather than a European power. When the U.S. rewarded Britain with benefits and status in defence cooperation, ${ }^{53}$ it nurtured in the British political-military elite a self-perception of being apart from - and superior to - European allies in defence. ${ }^{54}$

\section{Influences of the CAP on Colombia's passage through UNASUR}

\section{Entry into CDS-UNASUR influenced by a cooling CAP}

The Uribe Government entered UNASUR to avoid regional isolation following Operation Phoenix, an incursion into Ecuador which destroyed a FARC camp in March 2008. ${ }^{55}$ Colombia's adherence to the CDS was also motivated by the cooling of the CAP with the arrival of the liberal Barack Obama to the U.S. presidency. ${ }^{56}$

The creation of UNASUR as an organisation dedicated to regional security management was a process with such milestones as the signing of its Founding Treaty by South American leaders in May 2008 and the launch of the CDS in March 2009.

49 Frédéric Mauro, 'European defence: Mourning England’, Tribune, IRIS France, 22 January 2020.

50 Rees, 'America, Brexit'.

51 Ibid. 10.

52 In the event of disagreements with EU states, the U.S. often refused to coordinate a shared policy, and followed its own course. In the run-up to the Iraq War, America drew Britain into bilateral cooperation, limiting the role it could play in alliance management. Thus, the U.S. not only provoked a soft balancing response by France and Germany, but left Britain detached from the European mainstream (Ibid. 13).

53 Specifically, nuclear cooperation, reconnaissance imagery and communications intelligence, preferential access to conventional weapons, close institutional link between the armed forces.

54 Rees, 'America, Brexit', 10.

55 FARC: Revolutionary Armed Forces of Colombia. The attack killed FARC's "number two" Commander among twenty guerrillas.

56 Victor Mijares, 'Filling the structural gap: Geopolitical links explaining the South American Defense Council', Colombia Internacional no 101 (2019). 
Operation Phoenix sparked a diplomatic crisis with Ecuador and Venezuela: both severed relations with Colombia, and a militarised dispute with Venezuela ensued. South American leaders pushed Colombia to join the CDS project so as to avoid escalation with Venezuela and isolation in South America. ${ }^{57}$

Since January 2009, Uribe could not count any more on his close friend Bush in the White House. The CAP cooled down because the Obama Administration downgraded security in hemispheric relations and Colombia in the U.S. national security agenda. ${ }^{58}$ Obama also showed benevolence toward UNASUR, tolerating its mediation in intra- and interstate crises in South America. ${ }^{59}$

\section{Limited participation}

The military CAP, enhanced by Plan Colombia, discourages any meaningful Colombian participation in the UNASUR-CDS. Attractive opportunities under the liberal CAP (triangular cooperation and partnership with NATO) further distract Colombia from the South American cooperative security project.

\section{Uribe defends the ACD in competitive conduct within UNASUR - result converges with the CAP (also serves UNASUR)}

At a UNASUR summit in 2009, Uribe defended the ACD in preparation, which would grant the U.S. formal access to seven Colombian bases, causing an uproar in South America for its potential to alter the regional power balance.

Threatening to withdraw from UNASUR, Colombia managed to block a condemnation of the ACD despite adamant Venezuelan opposition and strong Brazilian reservations. ${ }^{60}$

The Obama Administration insisted that the U.S. military presence in Colombia would not affect neighbours. It ruled out deploying an anti-aircraft system in Colombia fearing that it would only embolden Uribe to launch an anti-FARC incursion into Venezuela. ${ }^{61}$ The Uribe Government went on signing the ACD even without U.S. guarantees to protect Colombia from external aggression. Uribe must have calculated that the mere formalisation of U.S. military presence in Colombia would deter Venezuela. ${ }^{62}$

The Obama Administration also wanted the ACD, but without provoking any ColombianVenezuelan armed conflict. Discussing the ACD with Uribe within UNASUR served both

\footnotetext{
57 Martha Ardila and Juan Andrés Amado, 'Continuidades y cambios en las relaciones de Colombia con sus países vecinos: 2008-2009, año crítico con Ecuador y Venezuela’, OASIS no 14 (2009).

58 Mijares, 'Filling the structural gap', 20.

59 During the 2009 Summit of the Americas, he met with his twelve South American colleagues.

60 Tom Long, Sebastián Bitar and Gabriel Jiménez-Peña, 'Domestic Contestation and Presidential Prerogative in Colombian Foreign Policy’, Bulletin of Latin American Research 39, no 4 (2020).

61 Consuelo Ahumada, 'Santos y el acuerdo militar con Estados Unidos: de la sumisión al pragmatismo', Portafolio, 13 January 2011.

62 Long, Bitar and Jiménez-Peña, 'Domestic Contestation’, 7.
} 
objectives. As a result of the summit, initial normative parameters for the presence of foreign military forces in South America were established. ${ }^{63}$

Summing up, Uribe's conduct within UNASUR was competitive, and the result converged with the mixed CAP. But it was also acceptable to UNASUR partners as a first step toward making Colombia take into consideration the regional consequences of its CAP commitments.

\section{Minimalism: Colombia's competitive behaviours within the CDS - converge with the military CAP}

Among CDS members, Colombia was the most averse to the idea of regional security autonomy. Colombian security cooperation remained bilateral and minimalist, focusing on the borders with Brazil, Peru and Ecuador. Colombians found it difficult to cooperate with Venezuelans within the CDS, and were uninterested in centralised decision-making. ${ }^{64}$

Radseck noted two limitations of Colombia to cooperate within the CDS: the aversion to publish data on its defence sector (white papers), and the constant commitment to cultivate the most intimate relationship with the Pentagon. This commitment was only reaffirmed by the military CAP's strategic reorientation from intervention by invitation (internal security) toward triangular cooperation (external security). ${ }^{65}$

\section{Cooperative behaviours within UNASUR - compatible with the liberal CAP}

Days after his inauguration in 2010, Santos meets with Venezuelan President Hugo Chávez - in the presence of UNASUR Secretary General Nestor Kirchner - to normalise the bilateral relationship. Chávez helped persuade FARC leaders to negotiate peace. Santos invited Venezuela to "accompany” the negotiations in La Havana. Obama quietly supported the peace process.

Santos lets the ACD perish (after the Constitutional Court conveniently tied its survival to Congressional ratification). This calmed Chávez, the ACD’s staunchest critic within UNASUR. Santos was also able to convince the U.S. that a formal agreement was not indispensable. U.S. operations (military training, drug interdiction, communications, intelligence) in Colombia continued by using "quasi-bases" without formal lease. ${ }^{66}$ The liberal CAP was not affected appreciably.

In 2014, Colombia’s Foreign Minister Ángela Holguín - with her colleagues of Brazil and Ecuador - tries to mediate in Venezuela between Nicolás Maduro's government and

63 Nolte, 'Cost and Benefits', 137.

${ }_{64}$ Mijares, 'Performance of the South American', 266, 273.

65 Michael Radseck, 'Las relaciones colombo-brasileñas de defensa: panorama actual', in Estado y perspectivas de las relaciones colombo-brasileñas, ed. by Daniel Flemes, Eduardo Pastrana and María Carpes (Bogotá: Editorial Pontificia Universidad Javeriana, 2017), 83-84.

66 Long, Bitar and Jiménez-Peña, 'Domestic Contestation’, 8. 
the opposition on behalf of UNASUR. U.S. Secretary of State John Kerry supported the mediation as long as it had a chance to enable a democratic transition in Venezuela. ${ }^{67}$

Thus, all these Colombian cooperative behaviours within UNASUR were acceptable to the Obama Administration.

\section{Santos's strategies concerning the UNASUR-OAS competition - under liberal and mixed CAPs}

Santos ends the Uribe-Chávez game of chicken. After the Uribe Government denounced in the OAS the presence of FARC camps in Venezuela, Chávez rejected the jurisdiction of the OAS, severed relations with Colombia, and requested a meeting of UNASUR. By receiving Chávez with Kirchner, Santos ceded to the Venezuelan president and legitimised UNASUR. $^{68}$

Santos attends an urgent UNASUR summit in Buenos Aires to condemn a coup attempt in Ecuador against left-wing President Rafael Correa in late 2010.

The UNASUR triad's mediation in Venezuela delays attempts in the OAS to trigger the Inter-American Democratic Charter procedure regarding the Maduro Government's alterations of the democratic order.

During a humanitarian crisis with Venezuela in 2015, Santos tries to combine the OAS and UNASUR by proposing to discuss in both fora the expulsion of Colombians and closure of the border. When the motion was blocked at the OAS, and Caracas delayed addressing the issue at UNASUR, Bogota withdrew the proposal to avoid another setback. ${ }^{69}$

Facing strong domestic resistance, Santos ends up sidelining UNASUR from the peace process. Although the United Nations accepted to verify implementation of the agreements, the OAS retained its support mission, winning the indirect competition with UNASUR.

At the end of his presidency, Santos - sharing the CAP with U.S. President Donald Trump - suspends Colombia's participation in UNASUR as part of a joint action of Lima Group members belonging to the South American organisation.

Note that the use of UNASUR alongside the OAS in the first five years of the Santos Presidency was compatible with the liberal CAP. Suspending participation in UNASUR came after the region's northward reorientation, under mixed CAP and Trump Administration pressure.

\footnotetext{
La Prensa, ‘Kerry apoya mediación de Unasur en Venezuela’, 08 April 2014.

Nolte, 'Costs and Benefits', 137.

Ibid. 143.
} 


\section{NATO partnership, triangular cooperation: balancing UNASUR-CDS collaterally - converging with liberal CAP}

Triangular cooperation and NATO partnership were promoted under the liberal ObamaSantos CAP. Challenging UNASUR's relevance was not its objective, but a side effect or, if anything, an afterthought.

At the 2012 Cartagena Summit of the Americas, Obama supported an initiative by Santos to export Colombian expertise in confronting transnational crime to Central America with U.S. co-financing. His backing gave a boost to this kind of triangular cooperation. ${ }^{70}$

Between 2010-2018, Colombian instructors trained more than 46 thousand officials from 81 countries in the fight against drugs, crime prevention and control, improvement of military and police forces, citizen security and organisational development: 60 per cent of them were trained in Central America under Colombian-American and ColombianCanadian cooperation programs. ${ }^{71}$

NATO members approved an Individual Program of Cooperation and Partnership for Colombia in 2017, recognising the country as their global partner. The request to NATO was made ten years earlier, when Santos was Uribe’s defence minister. ${ }^{72}$

In 2013, when Colombia signed an agreement with NATO to cooperate in peacekeeping operations, exchange confidential information, and fight organised crime and terrorism, Brazil and other left-wing governments questioned its commitment to the CDS. ${ }^{73}$ Some scholars also saw the deal as a tool in the hands of the Santos Government to buffer UNASUR and Brazil. ${ }^{74}$ Nevertheless, by 2018, when Colombia's global partner status was sealed during a visit by Santos to NATO headquarters, only one protester remained, the Bolivarian Government.

\section{Common narrative}

Plan Colombia and triangular cooperation underpinned a Colombian-American narrative about Colombia's transformation from a near-failed state into a security provider. ${ }^{75}$ This semi-official success story (although soon overshadowed by reality) helped nurture in

70 Eduardo Pastrana and Diego Vera, 'Colombia y su agenda de seguridad. Del gobierno de Juan Manuel Santos al gobierno de Iván Duque’, in La región frente a los cambios globales en materia de seguridad, ed. by Sandra Namihas (Lima: Equis Equis, 2019), 49.

71 'The Untapped Potential of the US-Colombia Partnership: Creating a Modernized Plan for the Bilateral Relationship’. Independent Task Force Report (Washington: Atlantic Council, 2019), 17.

72 Although UNASUR was formed in 2008, its predecessor, the South American Community of Nations, existed since 2004.

73 Brazilian Defense Minister Amorim expressed concern about the rapprochement of a CDS country to an extra-regional military alliance (El Universo, 'A Ecuador y Brasil les preocupa la relación Colombia-OTAN, comentario del ministro de defensa brasileño’, 07 June 2013).

74 Flemes and Castro, 'Institutional Contestation'.

75 Mateo Morales and Arlene Tickner, 'Narrando la historia del éxito: experticia en seguridad y política exterior en Colombia', in Nuevos enfoques para el estudio de las relaciones internacionales de Colombia, ed. by Arlene Tickner and Sebastián Bitar (Bogotá: Ediciones Uniandes, 2017). 
Colombia's political-military elite a self-perception of being distinct from, even superior to its neighbours in security.

Exit - loyalty to the U.S. and the OAS

As president-elect, Duque announces Colombia's exit from UNASUR in Washington, meeting Secretary General Almagro in OAS headquarters. After the August 2018 presidential inauguration, Bogotá is quick to notify UNASUR officially. Duque voiced two reasons: UNASUR was created to fracture the Inter-American System, and became an accomplice of the Venezuelan dictatorship. ${ }^{76}$

Although abandoning UNASUR was a Colombian gesture of loyalty to the U.S. and the OAS, ${ }^{77}$ it had little value. It was low-cost, because UNASUR lacked a trade dimension or solid institutionality. ${ }^{78}$ It was also irrelevant, since UNASUR already suffered a fatal blow in April, when its members of the Lima Group suspended their participation indefinitely. Just to make sure UNASUR's demise, Duque championed the creation of Prosur, another ideologically inspired regional scheme.

\section{Conclusions}

Britain's and Colombia's privileged bilateral relations with the U.S. influenced, directly or indirectly, their respective journey through the EC and UNASUR, including their entry, limited participation and exit - but they did it in rather different ways.

\section{Entries}

British and Colombian entry motivations - although had to do with the AASR and the CAP - had not much in common, except a feeling of regional isolation.

British entry to the EC was delayed by the vetoes of de Gaulle, who saw Britain as America's Trojan Horse. Then the sidelining of the AASR in transatlantic relations, as American diplomacy redirected towards the EC and Germany, gave a sense of urgency to accession.

The Uribe Government entered UNASUR to avoid regional isolation after Operation Phoenix, while its entry into the CDS was also motivated by the cooling of the CAP with liberal Obama's arrival to the White House.

76 EFE, 'Colombia notifica a la Unasur que deja el bloque por no denunciar la crisis venezolana', 28 August 2018.

77 Applauded by influential Republican Senator Rubio in a tweet.

78 Victor Mijares and Detlef Nolte, 'Regionalismo posthegemónico en crisis', Revista FAL 18, no 3 (2018). 


\section{Limited participations}

British participation in the Single Market was compatible with the AASR, but other cooperative options within the EC - like an adherence to the euro (collective soft balancing against the dollar) or to a European defence autonomy drive (inter-institutional balancing against NATO) - would have been incompatible.

Even the Blair Government (seen as pro-European) desisted from both projects. Since the start of the Iraq War, Britain (ostensibly on U.S. behalf) played a rather obstructive role in the CFSP-CSDP which in twenty years of complementation with NATO has not achieved strategic autonomy.

Although less significant, Colombian cooperative actions within UNASUR during the first half of the Santos Presidency resulted compatible with the liberal CAP (until the Venezuelan conflict became intractable, and Obama was replaced by Trump in the White House).

Tolerant with UNASUR (despite its dealing with security without U.S. participation), the Obama Administration did not use Colombia to hinder the CDS project. Yet the robust military CAP naturally discouraged any meaningful Colombian contribution to this security community initiative, promoted by Brazil.

Furthermore, cherished security projects of the liberal Obama-Santos CAP, such as triangular cooperation and NATO partnership, attracted Colombia's political-military elite way more than UNASUR, diminishing the latter's relevance collaterally.

\section{UNASUR-OAS competition}

Assigning a role to UNASUR - alongside the OAS - in South American security management was compatible with the liberal CAP, but not with the neoconservative CAP. Even a lopsided complementation - such as the one between NATO and the CSDP - proved unviable between the OAS and UNASUR.

\section{Mixed CAPs}

The compatibility of mixed CAPs with UNASUR remained inconclusive. Uribe under Obama joined the CDS, but soon threatened to leave UNASUR altogether in his defence of the agreement on bases with the U.S. Santos under Trump suspended participation in UNASUR, but did not abandon the organisation for good.

\section{Exits}

The AASR and the CAP - with their close military ties - nurtured in Britain and Colombia a self-perception of being distinct from, even superior to their neighbours in securitydefence, thus feeding their scepticism towards the CSDP and the CDS. 
Ironically, Britain's last status in the EC (partial in integration, full in decision-making) was optimal for the U.S., and Obama argued against Brexit.

But previous U.S. administrations - that used bilateral collaboration with Britain to manage their ambiguous relationship with European allies - inadvertently contributed to British Euroscepticism and hence to Brexit.

By contrast, Colombia's departure from UNASUR was formalised by the Duque Government as a gesture of loyalty to the U.S. and the OAS, under neoconservative CAP with the Trump Administration.

But Colexit was too low-cost since UNASUR had no trade dimension (contrary to Brexit's high costs to Britain for lost privileges on its largest market).

\section{References}

Ahumada, Consuelo, 'Santos y el acuerdo militar con Estados Unidos: de la sumisión al pragmatismo’. Portafolio, 13 January 2011. Online: www.portafolio.co/opinion/redaccionportafolio/santos-acuerdo-militar-estados-unidos-sumision-pragmatismo-151104

Ardila, Martha and Juan Andrés Amado, 'Continuidades y cambios en las relaciones de Colombia con sus países vecinos: 2008-2009, año crítico con Ecuador y Venezuela’. OASIS no 14 (2009), 55-70. Online: https://revistas.uexternado.edu.co/index.php/oasis/article/ view/2459/2094

Ashton, Nigel, ‘Harold Macmillan and the ‘Golden Days’ of Anglo-American relations revisited, 1957-63’. Diplomatic History 29, no 4 (2005), 691-723. Online: https://doi. org/10.1111/j.1467-7709.2005.00511.x

Brooks, Stephen and William Wohlforth, 'Hard Times for Soft Balancing'. International Security 30, no 1 (2005), 72-108. Online: https://doi.org/10.1162/0162288054894634

Brown, Rebekah, 'History of the Anglo-American Special Relationship'. Ashbrook Statesmanship Thesis, 2012. Online: https://ashbrook.org/wp-content/uploads/2012/06/ShermanBrownPrintable.pdf

Cladi, Lorenzo and Andrea Locatelli, 'Keep Calm and Carry On (Differently): NATO and CSDP after Brexit’. Global Policy 11, no 1 (2020), 5-14. Online: https://doi.org/10.1111/17585899.12747

Dabène, Olivier, 'La cuarta ola de regionalismo', in Los desafíos del desarrollo en América Latina, ed. by Carlos Quenan and Sébastian Velut. Paris: Institut des Amériques, 2014, 64-95. Online: www.afd.fr/es/ressources/los-desafios-del-desarrollo-en-america-latinadinamicas-socioeconomicas-y-politicas-publicas

EFE, ‘Colombia notifica a la Unasur que deja el bloque por no denunciar la crisis venezolana', 28 August 2018. Online: www.efe.com/efe/america/portada/colombia-notifica-a-la-unasurque-deja-el-bloque-por-no-denunciar-crisis-venezolana/20000064-3731560

El Universo, 'A Ecuador y Brasil les preocupa la relación Colombia-OTAN, comentario del ministro de defensa brasileño’, 07 June 2013. Online: www.eluniverso.com/ noticias/2013/06/07/nota/999936/preocupa-relacion-colombia-otan 
Flemes, Daniel and Rafael Castro, 'Institutional Contestation: Colombia in the Pacific Alliance'. Bulletin of Latin American Research 35, no 1 (2016), 78-92. Online: https://doi.org/10.1111/ blar.12411

Flemes, Daniel and Leslie Wehner, 'Drivers of strategic contestation: The case of South America'. International Politics 52, no 2 (2015), 163-177. Online: https://doi.org/10.1057/ip.2014.45

Frank, Robert, Être ou ne pas être Européen? Les Britanniques et l'Europe du XVIIe siècle au Brexit. Paris: Belin, 2018.

Freedman, Lawrence, 'Britain Adrift. The United Kingdom’s Search for a Post-Brexit Role’. Foreign Affairs, May-June 2020. Online: www.foreignaffairs.com/articles/unitedkingdom/2020-04-13/britain-adrift

He, Kai, 'Contested Regional Orders and Institutional Balancing in the Asia Pacific'. International Politics 52, no 2 (2015). Online: https://doi.org/10.1057/ip.2014.46

IRIS France, 'Être ou ne pas être européen? Les Britanniques et l’Europe du XVIIe siècle au Brexit - 3 questions à Robert Frank’. Le point de vue de Pascal Boniface, 28 March 2019. Online: www.pascalboniface.com/2019/03/28/etre-ou-ne-pas-etre-europeen-lesbritanniques-et-leurope-du-xviie-siecle-au-brexit-3-questions-a-robert-frank

Isacson, Adam, 'It’s Not Too Late for the Land of Mercenaries'. The New York Times, 05 August 2021. Online: www.nytimes.com/2021/08/05/opinion/colombia-mercenaries-haiti.html

Jiménez García, Edgar, ‘El ejército europeo y la PESCO: OTAN o nada’. Instituto Español de Estudios Estratégicos, Documento de Opinión no 97 (2019). Online: www.ieee.es/Galerias/ fichero/docs_opinion/2019/DIEEEO97_2019EDGJIM_EjercitoEuropeo.pdf

'Joint Declaration on European Defence, issued at the British-French Summit, Saint-Malo', 04 December 1998. Online: www.cvce.eu/obj/franco_british_st_malo_declaration_4_ december_1998-en-f3cd16fb-fc37-4d52-936fc8e9bc80f24f.html

Koppa, Maria Eleni, 'The relationship between CSDP and NATO after Brexit and the EU's Global Strategy’. FEPS Studies, April 2019. Online: www.feps-europe.eu/attachments/content/ relationship_cspd_nato_after_brexit.pdf

La Prensa, ‘Kerry apoya mediación de Unasur en Venezuela’, 08 April 2014. Online: www. laprensa.com.ni/2014/04/08/internacionales/190185-kerry-apoya-mediacion-de-unasur-envenezuela

Lake, David, 'International Legitimacy Lost? Rule and Resistance when America is First'. Perspectives on Politics 16, no 1 (2018), 6-21. Online: https://doi.org/10.1017/ S1537592717003085

Lee, Seungjoo, 'Institutional Balancing and the Politics of Mega-FTAs in East Asia'. Asian Survey 56, no 6 (2016), 1055-1076. Online: https://doi.org/10.1525/as.2016.56.6.1055

Lepage, Mélanie, Vers le développement d'une communauté de sécurité pluraliste en Amérique du Sud avec la mise en place de l'Union des nations sud-américaines. Essai de maîtrise, dirigé par Gordon Mace. Université Laval, IQHEI, Avril 2011. Online: www.cms.fss.ulaval.ca/ recherche/upload/cei/fichiers/essai_melanie_lepage_unasur.pdf

Lippert, Barbara and Nicolai Ondarza, 'Der Brexit als Neuland'. SWP Aktuell no 42 (2016). Online: www.swp-berlin.org/fileadmin/contents/products/aktuell/2016A42_lpt_orz.pdf

Long, Tom, Sebastián Bitar and Gabriel Jiménez-Peña, 'Domestic Contestation and Presidential Prerogative in Colombian Foreign Policy’. Bulletin of Latin American Research 39, no 4 (2020), 466-482. Online: https://doi.org/10.1111/blar.12987 
Mauro, Frédéric, ‘European defence: Mourning England’. Tribune, IRIS France, 22 January 2020. Online: www.iris-france.org/143794-european-defence-mourning-england

Mijares, Victor, 'Filling the structural gap: Geopolitical links explaining the South American Defense Council’. Colombia Internacional no 101 (2019), 3-28. Online: https://doi. org/10.7440/colombiaint101.2020.01

Mijares, Victor, 'Performance of the South American Defense Council Under Autonomy Pressures’. Latin American Policy 9, no 2 (2018), 258-281. Online: https://doi.org/10.1111/ lamp.12146

Mijares, Victor and Detlef Nolte, 'Regionalismo posthegemónico en crisis'. Revista FAL 18, no 3 (2018), 105-112. Online: http://revistafal.com/numeros-anteriores/fal-18-3

Morales, Mateo and Arlene Tickner, 'Narrando la historia del éxito: experticia en seguridad y política exterior en Colombia', in Nuevos enfoques para el estudio de las relaciones internacionales de Colombia, ed. by Arlene Tickner and Sebastián Bitar. Bogotá: Ediciones Uniandes, 2017, 239-262. Online: https://doi.org/10.7440/2017.52

'NATO and Colombia have concluded a partnership agreement', 19 May 2017. Online: www.nato. int/cps/en/natohq/topics_143936.htm

Nolte, Detlef, 'Costs and Benefits of Overlapping Regional Organizations in Latin America: The Case of the OAS and UNASUR'. Latin American Politics and Society 60, no 1 (2018), 128-153. Online: https://doi.org/10.1017/lap.2017.8

Pastrana, Eduardo and Diego Vera, 'Colombia y su agenda de seguridad. Del gobierno de Juan Manuel Santos al gobierno de Iván Duque’, in La región frente a los cambios globales en materia de seguridad, ed. by Sandra Namihas. Lima: Equis Equis, 2019.

Posen, Barry, 'EU security and defence policy: Response to unipolarity?’ Security Studies 15, no 2 (2006), 149-186. Online: https://doi.org/10.1080/09636410600829356

Radseck, Michael, 'Las relaciones colombo-brasileñas de defensa: panorama actual', in Estado y perspectivas de las relaciones colombo-brasileñas, ed. by Daniel Flemes, Eduardo Pastrana and María Carpes. Bogotá: Editorial Pontificia Universidad Javeriana, 2017, 57-92. Online: https://doi.org/10.2307/j.ctv86dgnp.5

Rees, Wyn, 'America, Brexit and the security of Europe'. British Journal of Politics and International Relations 19, no 3 (2017), 558-572. Online: https://doi. org/10.1177/1369148117711400

Reynolds, David, ‘A ‘special relationship’? America, Britain and the international order since the Second World War'. International Affairs 62, no 1 (1985), 1-20. Online: https://doi. org/10.2307/2618063

'The Untapped Potential of the US-Colombia Partnership: Creating a Modernized Plan for the Bilateral Relationship'. Independent Task Force Report, Washington: Atlantic Council, 2019. Online: www.atlanticcouncil.org/in-depth-research-reports/report/untapped-potentialus-colombia-partnership

Valášek, Tomáš, 'European defense vs. NATO: Not the right fight’. Politico, 19 February 2018. Online: www.politico.eu/article/european-defense-vs-nato-not-the-right-fight

Weiffen, Brigitte, Leslie Wehner and Detlef Nolte, 'Overlapping regional security institutions in South America: The case of OAS and UNASUR'. International Area Studies Review 16, no 4 (2013), 370-389. Online: https://doi.org/10.1177/2233865913503466 